\title{
Lower Jurassic brachiopods from the Ibero-Levantine Sector (Iberian Range): Faunal turnovers and critical bioevents
}

\author{
J.F. Baeza-Carratalá1* , F. García Joral², J.E. Tent-Manclús ${ }^{1}$ \\ ${ }^{1}$ Dpt. de Ciencias de la Tierra y Medio Ambiente, Universidad Alicante, Apdo. 99, San Vicente del Raspeig, 03080 Alicante, Spain \\ ${ }^{2}$ Dpt. de Paleontología, Facultad de Ciencias Geológicas, Universidad Complutense, c./ José Antonio Novais, 12, 28040 Madrid, Spain \\ e-mail addresses: jf.baeza@ua.es (J.F.B-C., *Corresponding author); fgjoral@ucm.es (F.G.J.); je.tent@ua.es (J.E.T-M.)
}

Received: 11 July 2016 / Accepted: 4 October 2016 / Available online: 20 December 2016

\begin{abstract}
Brachiopod fauna from the peri-Iberian platform system is well-known in the Late Pliensbachian-Toarcian interval. However, the diversity dynamics and the stratigraphical distribution of this group in the Ibero-Levantine Sector of the Iberian Range require more accurate analysis due to the patchy distribution of the outcrops. The abovementioned timespan involved a period of changes in long-term environmental conditions which led to a severe extinction and critical turnovers on the brachiopod fauna (ETMEE). The Ibero-Levantine sector has notable palaeobiogeographical significance as it represents the south-easternmost outcrops of the Iberian Range connecting with the Betic Domain positioned in the South-Iberian Palaeomargin. In this region, the brachiopod fauna has been arranged into six assemblages, showing a discontinuous stratigraphic distribution since its diversity dynamics is markedly conditioned by the extinction phases linked to the ETMEE: Ass. 1, recorded in the Spinatum-lower Tenuicostatum chronozones; Ass. 2, mainly recorded in the Tenuicostatum chronozone; Ass. 3, typifying the lower Serpentinum chronozone; Ass. 4, documented in the Serpentinum-lowermost Bifrons chronozones; Ass. 5, recorded in the Bifrons-Variabilis chronozones, and Ass. 6, distinctive of the Pseudoradiosa-Aalensis chronozones.

The faunal succession shows strong affinities with the Euro-Boreal province, what rules out the transitional or even Mediterranean palaeogeographical affinity previously attributed to the southernmost part of this area. Amidst the main brachiopod-based bioevents must be considered the predominance of the genus Lobothyris in the pre-ETMEE assemblages, the conspicuous record of Liospiriferina? undulata, distinctive taxon of the north-African margin and, especially, the first record in the Iberian Peninsula of thecideid marker beds prior to the ETMEE. After the opportunistic strategy conducted by Soaresirhynchia bouchardi the distribution of the post-ETMEE brachiopod assemblages is markedly influenced by the depositional sequences, entailing premature turnovers and involving the earlier record of homeomorphic morphotypes of younger terebratulides and rhynchonellides.
\end{abstract}

Keywords: Brachiopods, Western Tethys, Early Jurassic, palaeobiogeography, mass extinction, faunal turnovers

\section{Resumen}

Las sucesiones de braquiópodos en el Pliensbachiense superior-Toarciense, ampliamente reconocidas en las plataformas marginales de Iberia, carece de un registro preciso en el sector Ibero-Levantino de la Cordillera Ibérica. Este intervalo engloba un periodo de cambios ambientales significativos, incluyendo un severo evento de extinción y reemplazamiento que condiciona notablemente la distribución de los braquiópodos (ETMEE). El sector Ibero-Levantino posee un especial interés paleobiogeográfico, representando el extremo sudoriental de la Cordillera Ibérica, en contacto con los afloramientos de directriz Bética del paleomargen sud-Ibérico. En esta región, se han definido seis asociaciones que muestran gran similitud con las del resto de áreas epicontinentales de la Cordillera Ibérica, si bien presentan unos bioeventos diferenciadores: As. 1, registrada en la cronozona Spinatum-parte baja de Tenuicostatum; As. 2, fundamentalmente reconocida en la cronozona Tenuicostatum; As. 3, característica de la cronozona Serpentinum (parte basal); As. 4, registrada en las cronozonas Serpentinumparte inferior de Bifrons; As. 5, distintiva de las cronozonas Bifrons-Variabilis y As. 6, típica de las cronozonas Pseudoradiosa-Aalensis. Paleobiogeográficamente, no se registra (pre-ETMEE) ningún taxón distintivo de la provincia Mediterránea, al contrario que en las cuencas béticas contiguas, descartándose el carácter transicional e incluso "bético" que se confería a los afloramientos meridionales de esta región. Entre los bioeventos excepcionales cabe destacar el primer hallazgo de un nivel guía pre-ETMME de Thecideidos, no documentado hasta 
el momento en el resto de plataformas marginales de Iberia. También es diferenciador el bioevento pre-ETMEE de máxima diversidad y abundancia de Liospiriferina? undulata, taxón característico del margen nord-africano, así como una mayor persistencia del género Lobothyris. Tras el ETMEE, se aprecia la estrategia oportunista de Soaresirhynchia bouchardi y una prematura aparición de la As. 5 respecto al resto de la Cordillera Ibérica, confirmando la estrecha relación entre las sucesiones faunísticas y los continuos cambios de facies durante el Toarciense-Aaleniense.

Palabras clave: Braquiópodos, Tethys occidental, Jurásico Inferior, paleobiogeografía, extinción masiva, reemplazamiento faunístico

\section{Introduction}

Lower Jurassic brachiopods have been widely documented in the Iberian Range, especially in the Pliensbachian-Toarcian interval (Dubar, 1931; Goy and Robles, 1975; ComasRengifo and Goy, 1975; Goy et al., 1984; 1997; García Joral and Goy, 1984, 1994, 2000, 2004; García Joral et al., 1990, 2011; Comas-Rengifo et al., 1998, 2006, among others). Whereas an extensive research has been carried out on the brachiopod faunas of the northern and innermost areas of the basin (Castilian and Aragonese branches), the Ibero-Levantine Sector (I-LS hereinafter) of the Iberian Range remains insufficiently studied, probably due to the patchy distribution of the outcrops, particularly in the southern part of this region (Gómez, 1979).

The Ibero-Levantine region is located in a strategic palaeobiogeographical situation, representing the south-easternmost outcrops of the Iberian Range connecting with the Betic Domain positioned in the South-Iberian Palaeomargin. The epicontinental carbonate environments in this region are prolific in macroinvertebrates (mainly bivalves, ammonites and brachiopods). The detailed analysis of brachiopod assemblages for the first time in this area and the calibration of its distribution with the exhaustively controlled biochronological ammonite data at zone (even biohorizon) level in the Iberian Range (Goy, 1974; Goy et al., 1988; Goy and Martínez, 1990) contribute to a better understanding the palaeobiogeographic evolution (at a regional and global scale) of the periIberian platform system established during the Early Jurassic.

The Lower Jurassic brachiopod successions in the I-LS are recorded in the uppermost Pliensbachian-Upper Toarcian interval, comprising a period of changes in long-term environmental conditions (e.g. Little and Benton, 1995; Wignall et al., 2005; cf. Wignall and Bond, 2008; Caswell et al., 2009) which led to a main biotic crisis event (Early Toarcian Mass Extinction Event, ETMEE) entailing a conspicuous extinction and severe turnover of the brachiopod fauna (e.g. Little and Benton, 1995; Vörös, 2002; García Joral et al., 2011; Baeza-Carratalá et al., 2015; Vörös et al., 2016). In the I-LS outcrops, the dynamics of the brachiopod assemblages is markedly conditioned by this event, showing a high diversity in the assemblages but with a discontinuous stratigraphic distribution related with the extinction phases linked to the ETMEE. Thus, the analysis of the assemblages, diversity turnovers and the main brachiopod-based bioevents prior to the ETMEE and their posterior recovery in this area, improves the knowledge of the ecological effects of this event in the
peri-Iberian basins, which include one of the most conspicuous brachiopod records around the ETMEE in the westernmost Tethyan Ocean.

Previous significant contributions to the knowledge of the Lower Jurassic Ibero-Levantine brachiopods were scarce, e.g. by Bizon et al. (1966) and Champetier $(1971,1972)$, who reported brachiopod occurrences restricted to the Spinatum Zone and the Pliensbachian-Toarcian transition. The subsequent comprehensive stratigraphical work of Gómez (1979) revealed, in the Sot de Chera locality (besides of Rhynchonella cf. dumbletonensis, Spiriferina rostrata and Lobothyris arcta, prior to the ETMEE), the first evidence of post-ETMEE brachiopod fauna, reporting $S$. bouchardi together with several typical Middle-Upper Toarcian taxa. This work also included several outcrops northwards containing brachiopods with predominance of $H$. meridionalis and $S$. bouchardi.

The present work reveals the variations in the diversity and taxonomical composition of the brachiopod assemblages prior to- and post-ETMEE, up to their total recovery in the Middle-Late Toarcian times. This analysis suggests several brachiopod-based bioevents, such as the conspicuous occurrence of micromorphic, mainly thecideoid representatives, which typify a pre-ETMME marker bed in the I-LS. This bioevent is recorded for the first time in the Iberian Range as well as in the entire peri-Iberian platforms system.

Analyzing the distribution and calibrating the Ibero-Levantine brachiopod assemblages enable their use, not only for the palaeogeographical reconstructions, but also for biostratigraphical purposes as being achieved in all other periIberian platforms (Goy et al., 1984; García Joral et al., 1990, 2011; Fernández-López et al., 1998; García Joral and Goy, 2000; 2009, 2010; Baeza-Carratalá and García Joral, 2012; Baeza-Carratalá, 2013; Comas-Rengifo et al., 2015; BaezaCarratalá et al., 2016).

Finally, this work also improves the knowledge of the Middle-Late Toarcian assemblages of the Iberian Range, which have notable palaeobiogeographic implications due to their potential for dispersion throughout the peri-Laurasian epicontinental platforms (Andrade, 2006; Baeza-Carratalá and Sepehriannasab, 2014; Andrade et al., 2016).

\section{Geological and stratigraphical setting}

Several Jurassic localities have been prospected in the I-LS of the Iberian Range. The outcrops are often patchily distributed and discontinuous but some localities allow bed-by-bed sampling. Three of these localities (Racó de Joana, Benifairó- 


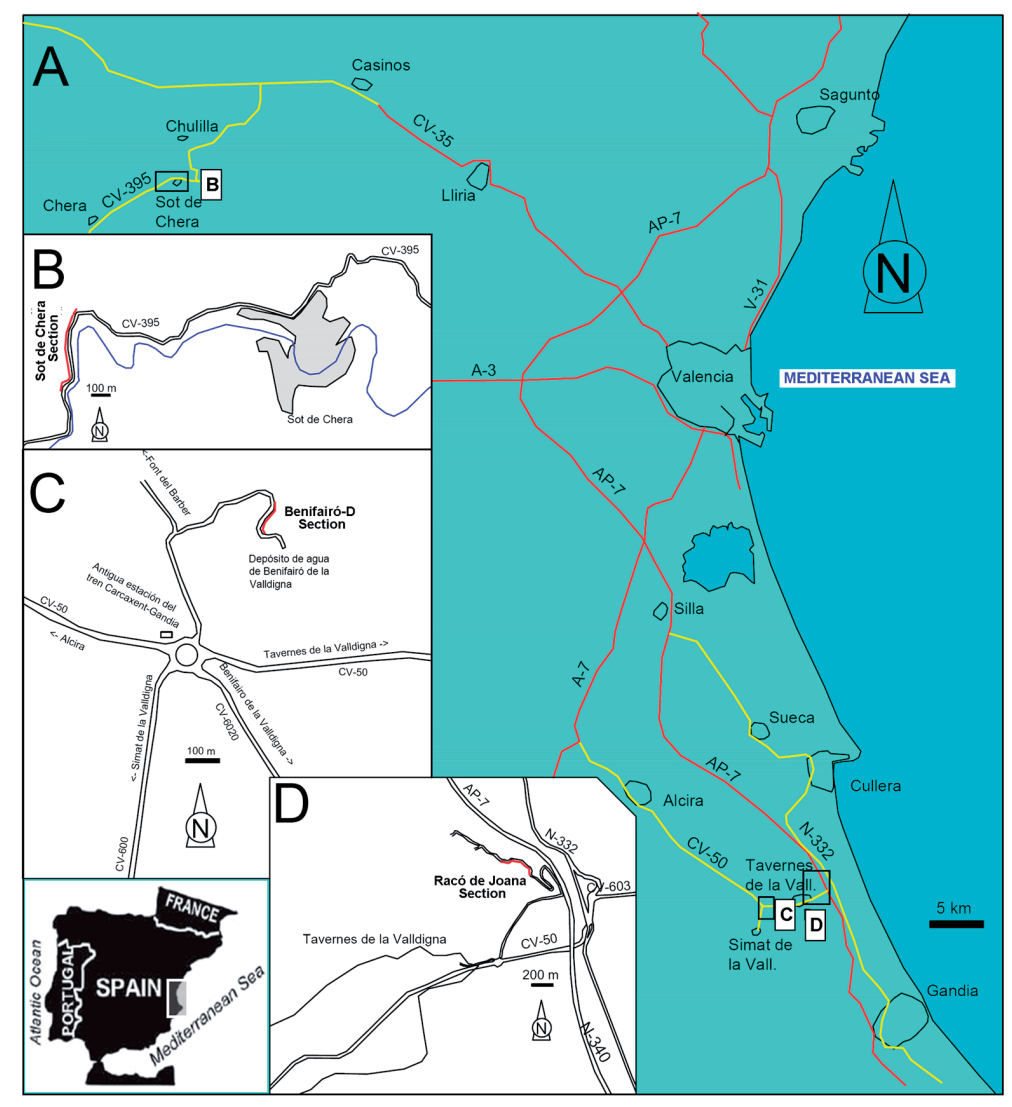

Fig. 1.- A. Geographical situation of the sampled localities in the Ibero-Levantine sector of the Iberian Range (Valencia province, Spain). Stratigraphical sections are detailed in B: Sot de Chera section, C: Benifairó-D section, and D: Racó de Joana section.

D, and Sot de Chera) located in the Valencia province (East Spain), have been selected being the most appropriate to establish brachiopod successions in this sector (Fig. 1).

The Ibero-Levantine sector (sensu Gómez, 1979) comprises the southernmost Jurassic outcrops of the Iberian Range, close to the Prebetic outcrops (Fig. 2). Northwards, this sector gives way to the Castilian branch, bordering to the Northwest with the Aragonese branch of the Iberian Range (Fig. 2). All of them together with the South Iberian palaeomargin (mainly represented by the Betic Domain), the Lusitanian, Asturias and the Basque-Cantabrian basins, constituted a system of platforms distributed around the Iberian Subplate in the Early Jurassic (Gómez and Goy, 2005).

The lithostratigraphic framework of the Lower Jurassic outcrops is quite similar in all regions of the Iberian Range (Gómez et al., 2003). The Upper Pliensbachian-Toarcian sediments are represented, from bottom to top, by the Barahona Fm., Turmiel Fm., and Casinos Fm. (Fig. 2).

In the studied outcrops, the Barahona Fm. is mainly composed by grayish to yellowish-red bioclastic grainstonepackstone beds with abundant bivalves (mainly ostreids) and crinoids; individual beds are less than $1 \mathrm{~m}$-thick. The top of this unit is marked by a $0.5 \mathrm{~m}$-thick, orange-color, condensation level bounded by two hardground levels (Goy et al., 1976). It is rich in skeletal remains, mainly corresponding to bivalves, gastropods, brachiopods, and scarce echinoids, and is especially developed in the Sot de Chera and Racó de Joana sections (Fig. 3). These deposits are referred as "Barahona hardground" (cf. Goy et al., 1976).
From the Pliensbachian-Toarcian transition onwards, the facies dominating all the outcrops are an alternation of grey and yellowish marls and mudstone beds of the Turmiel Fm. (Figs. 4, 5), which are arranged into deepening- and shallowing-upwards sequences (Gómez and Goy, 2000). At the bottom of this unit, a discontinuous shell-bed consisting of abundant brachiopod specimens can be found in Racó de Joana and Benifairó-D sections.

Finally, the Casinos Fm. characterizes the Middle-Upper Toarcian deposits with a sedimentation related with the onset of progradation of a marginal carbonate platform (Gómez and Goy, 2005). This unit is mainly composed of grayish mudstone to wackestone beds commonly with marly levels interspersed. They are well-bedded strata arranged in thin (10 to $20 \mathrm{~cm}$-thick) layers. Some set-layers of this unit show characteristic kidney-shaped bedding surfaces and, in the upper part of the Benifairó-D section, the calcareous sedimentation becomes thicker and more massive (Figs. 4, 5).

The record of the bottom of the Casinos Fm., and hence the onset of the mainly carbonate sedimentation, has proved to be relevant for the distribution of the brachiopod fauna as discussed later. In the Early-Middle Jurassic, the Iberian Range suffered a strong differentiation of the basin. As a consequence, evident variation of facies, thickness and development of disconformities occurred (cf. Gómez and Goy, 1979, 1981; García Joral et al., 1990). Thus, the transition from the marly Turmiel Fm. to the calcareous Casinos Fm. can be regarded as diachronic (Gómez, 1979), since it took place earlier in the I-LS (Bifrons-Variabilis zones) than in the 


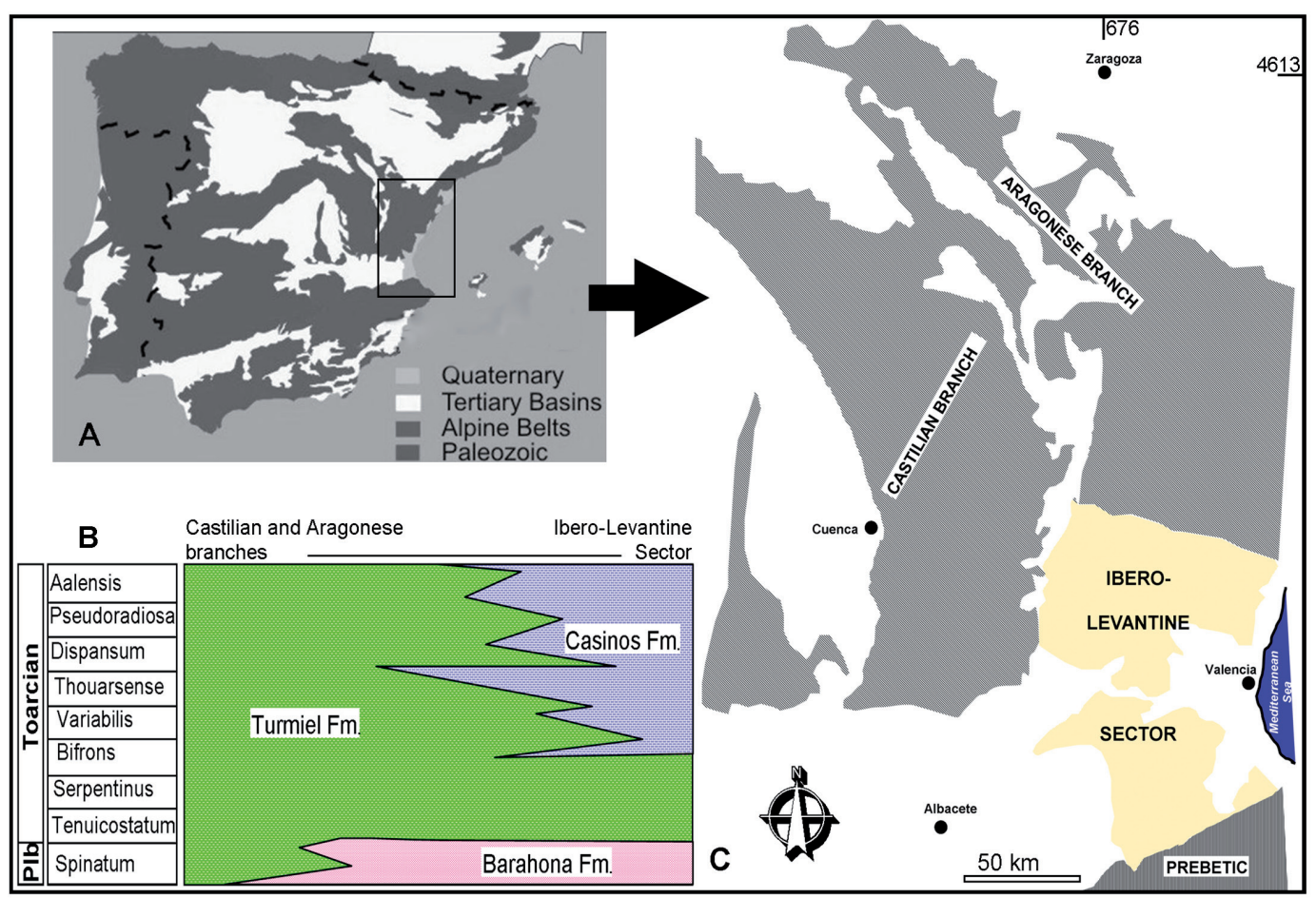

Fig. 2.- A. Geological setting of the Ibero-Levantine sector within the major geological domains of the Iberian Peninsula. B. Simplified sketch showing the lithostratigraphical framework of the Lower Jurassic formations in the studied area (slightly modified after Gómez and Goy, 2005). C. Regional geological sketch of the Ibero-Levantine outcrops in relationship to neighbouring areas.

remaining areas of the Iberian Range (Pseudoradiosa ZoneLower Bajocian), noticeably conditioning the distribution of the brachiopod successions (García Joral et al., 1990).

\section{Materials and methods}

Brachiopod-bearing deposits were analysed and sampled bed by bed. The samplings yielded 1692 specimens in three stratigraphic sections which contain the most complete and fossil-rich successions: Sot de Chera, Benifairó-D, and Racó de Joana (Fig. 1). Sot de Chera section partially corresponds to the section with the same denomination previously studied by Gómez (1979). Benifairó-D and Racó de Joana sections were previously sampled respectively as "Fuente del Barbero" and "Recó Juana" (sic) sections (Bizón et al., 1966; Champetier, 1971, 1972).

Generic assignments follow the published diagnoses mainly in the Treatise (Kaesler and Selden, 1997-2007). The internal structure of the thecideid fauna was directly studied under the stereo microscope on both disarticulated pedicle and brachial valves. All specimens were coated with magnesium oxide before photographing. High-resolution images were taken for the micromorphic thecideid fauna. All specimens are deposited at Departamento de Ciencias de la Tierra y del Medio Ambiente (University of Alicante, Spain).

The ammonite zonal/subzonal scheme follows the standard proposed by Dommergues et al. (1997), Elmi et al. (1997) and Page (2003) for the Jurassic of the NW-European Domain.

\section{Compositional analysis and assemblages distribution}

Brachiopod fauna from the I-LS can be arranged into six assemblages. These assemblages, albeit showing some distinguishing attributes, reveal a great similarity with those recorded in the remaining epicontinental platforms from the Iberian Range. Thus, they have been determined following the same palaeobiogeographic and chronostratigraphic criteria established in such areas (e.g. García Joral and Goy, 2000; García Joral et al., 2011):

Assemblage 1 (Figs. 4-6): [=Ass. 1 (partim García Joral and Goy, 2000; in toto García Joral et al., 2011)]. It consists of Lobothyris gr. punctata (Sowerby, 1813), L. subpunctata (Davidson, 1851), Aulacothyris resupinata (Sowerby, 1816), and Liospiriferina nicklesi (Corroy, 1927). It is recorded at the top of the Barahona Fm., or equivalent levels and in the overlying lower beds of the Turmiel Fm. It occurs in the Spinatum-lowermost Tenuicostatum chronozones.

Assemblage 2 (Figs. 4-6): [=Ass. 1 (partim García Joral and Goy, 2000); =Ass. 2 (García Joral et al., 2011)]. It is represented by Quadratirhynchia attenuata (Dubar, 1931), Liospiriferina? undulata (Seguenza, 1883), Liospiriferina sp. ind., Lobothyris arcta (Dubar, 1931), and a copious thecideid fauna (mainly arranged as Eudesella specimens), as index taxa. This assemblage also includes regularly associated Aulacothyris iberica (Dubar, 1931), Dispiriferina? oxyptera (Buvignier, 1843) and Liospiriferina cf. terebratuloides (Seguenza, 1883) as representative fauna. It is recorded in the Turmiel Fm., occurring in the Tenuicostatum Chronozone, 
though several taxa can co-occur with the Assemblage 1 in the uppermost Spinatum Zone.

Assemblage 3 (Figs. 4, 6): [=Ass. 2 (García Joral and Goy, 2000); =Ass. 3 (García Joral et al., 2011)]. It appears as monospecific concentrations of Soaresirhynchia bouchardi (Davidson, 1852) but the last records of this taxon can be found together with several Rhynchonellids belonging to the subsequent assemblage (Ass. 4). It is recorded in the Turmiel Fm. occurring in the lower part of the Serpentinum Chronozone (usually recorded in the Elegantulum Subzone).

Assemblage 4 (Figs. 4, 5, 7): [=Ass. 3 (García Joral and Goy, 2000); =Ass. 4 (García Joral et al., 2011)]. It is made up by Homoeorhynchia meridionalis (Deslongchamps, 1863), H. batalleri (Dubar, 1931), Pseudogibbirhynchia ex gr. jurensis (Quenstedt, 1858), Telothyris jauberti (Deslongchamps, 1863), T. pyrenaica (Dubar, 1931), and Lobothyris? hispanica (Dubar, 1931). They typify the so-called "Spanish Bioprovince" of brachiopods (García Joral and Goy, 1984; 2000; García Joral et al., 2011). It is recorded in the Turmiel Fm., occurring in the Serpentinum- (lowermost) Bifrons chronozones.

Assemblage 5 (Figs. 4, 5, 7): [=Ass. $4+$ Ass. 5 (García Joral and Goy, 2000)]. It includes Homoeorhynchia? marini (Rousselle, 1975), H. pusilla García Joral and Goy, 2010, Choffatirhynchia aff. turolensis García Joral and Goy, 2004,
Rhynchonelloidea aff. goyi García Joral, 1983, Pseudogibbirhynchia ex gr. jurensis s.l. (Quenstedt, 1858), a closely related (but different) species with that aforementioned in the Ass. 4, Telothyris sp. 1, Stroudithyris aff. infraoolithica (Deslongchamps, 1871), Stroudithyris sp., and Neozeilleria cf. lycetti (Davidson, 1851) as representative taxa. It is recorded in the Casinos Fm., occurring in the Bifrons-Variabilis chronozones.

Assemblage 6 (Fig. 5): [=Ass. 6 (García Joral and Goy, 2000)]. This assemblage is only represented in this sector by the occurrence of scarce and very fragmentary specimens of Rhynchonelloidea goyi García Joral, 1983, and large-sized unspecified terebratulids. It is recorded in the Casinos Fm., occurring in the Pseudoradiosa-Aalensis chronozones.

\section{Discussion. Critical bioevents and faunal turnovers}

Brachiopod faunal successions from the I-LS are recorded in the uppermost Pliensbachian-Toarcian interval. This timespan comprised a period of long-term environmental changes entailing a severe biotic crisis for the Mesozoic epibenthic biota, giving rise to a conspicuous extinction event (ETMEE) and/or severe turnovers on the brachiopod fauna (e.g. Little and Benton, 1995; Vörös, 2002; García-Joral et al., 2011; Baeza-Carratalá et al., 2015; Ruban and Vörös, 2015). In the
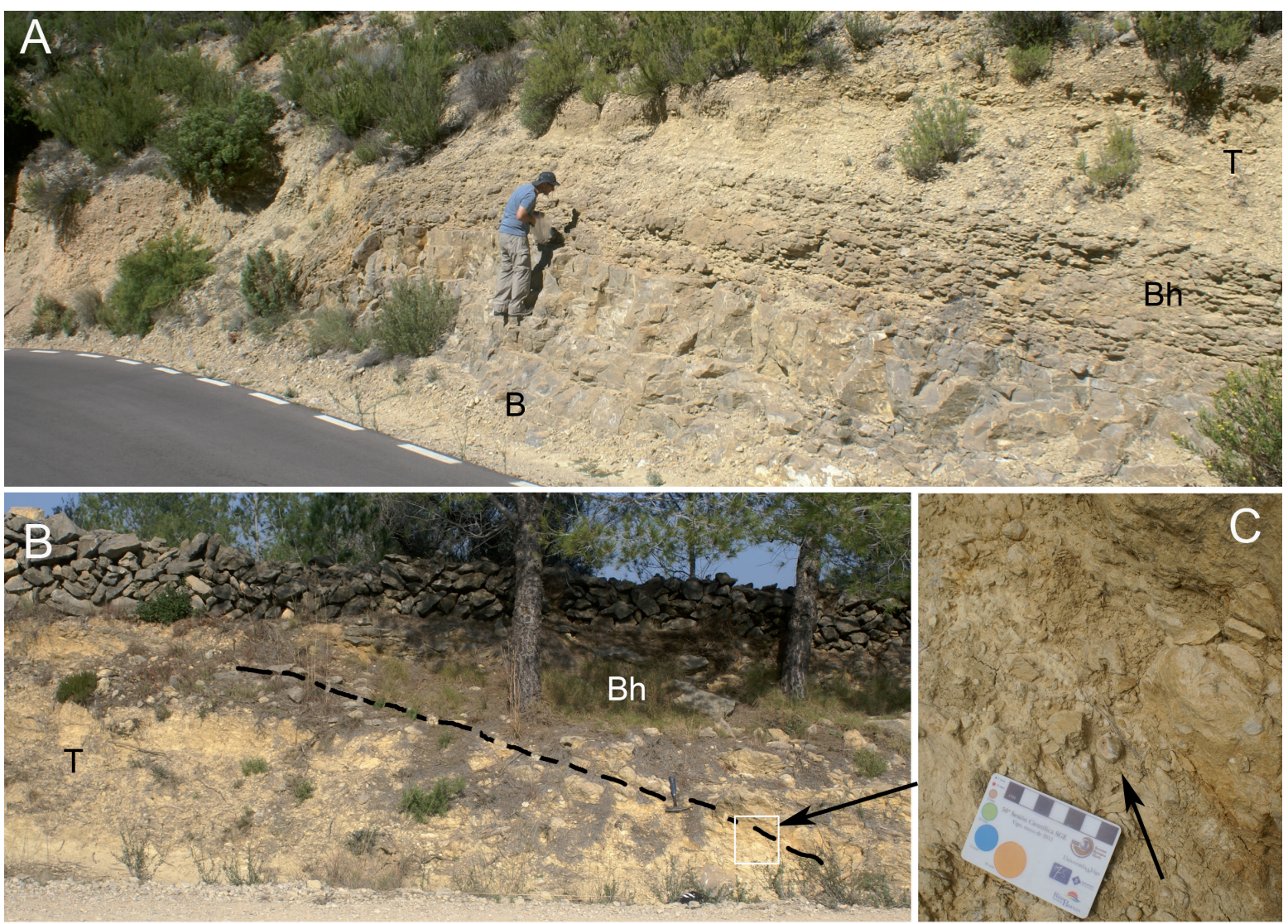

Fig. 3.- Field views of the Lower Jurassic outcropping sections at several localities. A. Lower part of the Sot de Chera section showing the bottom layers consisting of the Barahona Fm. (B), with condensation levels marking an unconformity at the top known as the "Barahona-hardground" (Bh), overlaid by the marly beds of the Turmiel Fm. (T). B. Comparable levels in the Raco de Joana section; note the overturned bedding in this section (the top is to the left of the image). C. Detail view of the basal beds of the Turmiel Fm.; black arrow marks a specimen of Quadratirhynchia attenuata. 


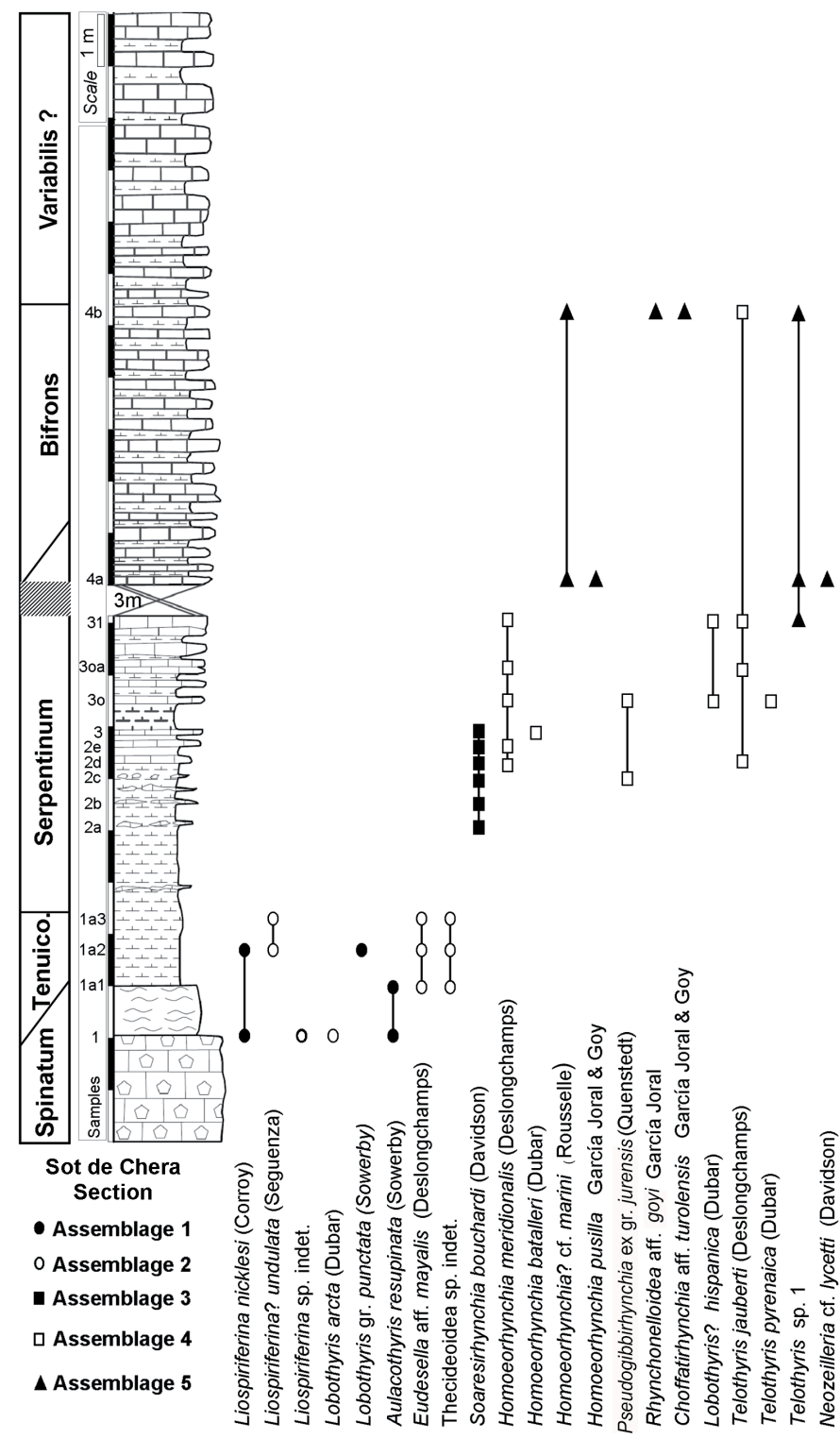

Fig. 4.- Distribution of the assemblages and brachiopod occurrences in the Sot de Chera section.

I-LS, the diversity dynamics of the brachiopod assemblages is markedly conditioned by this event, showing a high diversity in the assemblages but with a discontinuous stratigraphic distribution related with the extinction and recovery phases linked to the ETMEE (Figs. 4, 5).

The analysis of the established assemblages in this area suggests multiple distinctive diversity turnovers and critical brachiopod-based bioevents, which distinguish them from the adjacent palaeogeographic domains:

\subsection{Palaeobiogeographical pre-ETMEE affinities}

From a palaeobiogeographical standpoint, in the I-LS, taxa exclusively representative from the Mediterranean bioprovince are not recorded prior to the ETMEE. In the Upper Pliensbachian-lowermost Toarcian deposits, except for the thecideid fauna (discussed below), all the species are inte- grated in the assemblages previously reported from the Iberian Range, which are well established as belonging to the NW-European (Euro-Boreal) epicontinental bioprovince (cf. Ager, 1967, 1971; Delance, 1972; Vörös, 1977, 1984, 2016; García Joral and Goy, 2000; Manceñido, 2002; García Joral et al., 2011) or even have ubiquitous character (L. gr. punctata, $A$. resupinata). In the adjacent Betic basins, the Mediterranean affinity is evidenced since the late Sinemurian up to the early Toarcian (Baeza-Carratalá and García Joral, 2012; Baeza-Carratalá, 2013). After the extinction, faunal unification occurred indicating a free connection between the Subboreal and Mediterranean bioprovinces in the South-Iberian palaeomargin (Baeza-Carratalá et al., 2011; Baeza-Carratalá, 2013).

Therefore it should be ruled out the allegedly transitional Betic/Iberian palaeogeographical character or even the "Betic" affinity that previous authors attributed to the southernmost outcrops of the I-LS (cf. Bizon et al., 1966; Champetier, 1971), such as Racó de Joana and Benifairó-D.

\subsection{Event of proliferation of Liospiriferina? undulata}

Liospiriferina? undulata sensu lato, including Spiriferina madagascariensis (Thevenin, 1908) and probably several species grouped into the genus Calyptoria by Cooper (1989) and Alméras et al. (2010) are typical and abundant representatives of the assemblages from the Madagascariense Zone of the North-East African and the Middle-East platforms (Thevenin, 1908; Alméras, 1987; Cooper, 1989; Alméras and Mouty, 2001; Chiocchini et al., 2002), reaching in its dispersion North-East Sicily (Seguenza, 1885), and the periIberian platform system in Portugal (Comas-Rengifo et al., 2013), Betic Range (Baeza-Carratalá, 2013; Baeza-Carratalá et al., 2016), Catalonia (Delance, 1969; Calzada, 1979) and the Iberian Range (Rousselle, 1977; Comas-Rengifo et al., 2006; García Joral et al., 2011). In the I-LS of the Iberian Range, this taxon shows the greatest profusion and intraspecific variability among all the peri-Iberian platforms (Fig. 6). The occurrence of $L$.? undulata in this region is restricted to a few levels (Figs. 4, 5), probably coinciding with the thermal maximum, just prior to the ETMEE (cf. Gómez and Goy, 2011; García Joral et al., 2011; Baeza Carratalá et al., 2015).

\subsection{Thecideid marker horizon}

The conspicuous occurrence of several thecideid taxa, most of them consisting of remarkably large-sized specimens (Fig. 8), typifies a regional pre-ETMEE marker horizon ("thecideid beds") which enables correlations among the Lower Jurassic outcrops of the I-LS. Thus far, in the Iberian Range, thecideids are very sparse and have only been occasionally recorded. Mayoral and Sequeiros (1981) figured one specimen from the Toarcian reinterpreted as belonging to thecideids by Manceñido and Damborenea (1990), and Gahr (2002) figured a couple of specimens attributed to Davidsonella moorei from 


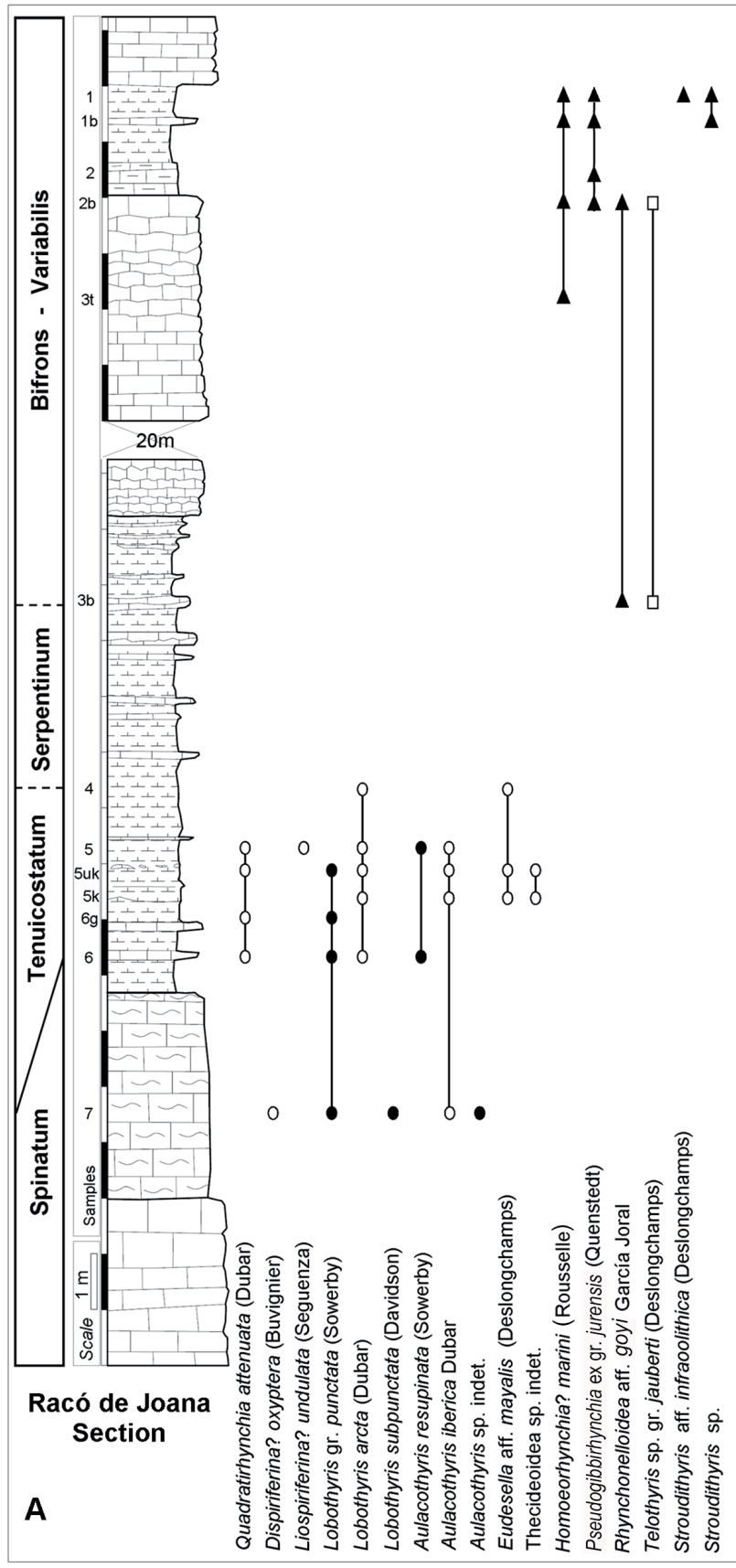

the Aragonese branch of the Iberian Range. Recently, new samplings by one of the authors (FGJ) have also confirmed the occurrence of the group in the Late Toarcian of the Castilian branch of the Iberian Range. There are also undescribed thecideid records in the Oxfordian (Colás Gracia, 2015). All these records of micromorphic thecideids correspond to more recent sediments than the pre-ETMEE "thecideid beds" of the I-LS.

Among the abundant specimens appearing in the thecideid beds, several micromorphic forms could be only uncertainly identified (Thecideida sp. ind.) due to the fragmentary character of the shells and the paucity of the material, making the analysis of their internal structures unfeasible. The prevailing taxon in this assemblage (Fig. 8) has been tentatively assigned to Eudesella aff. mayalis (Deslongchamps, 1853). The
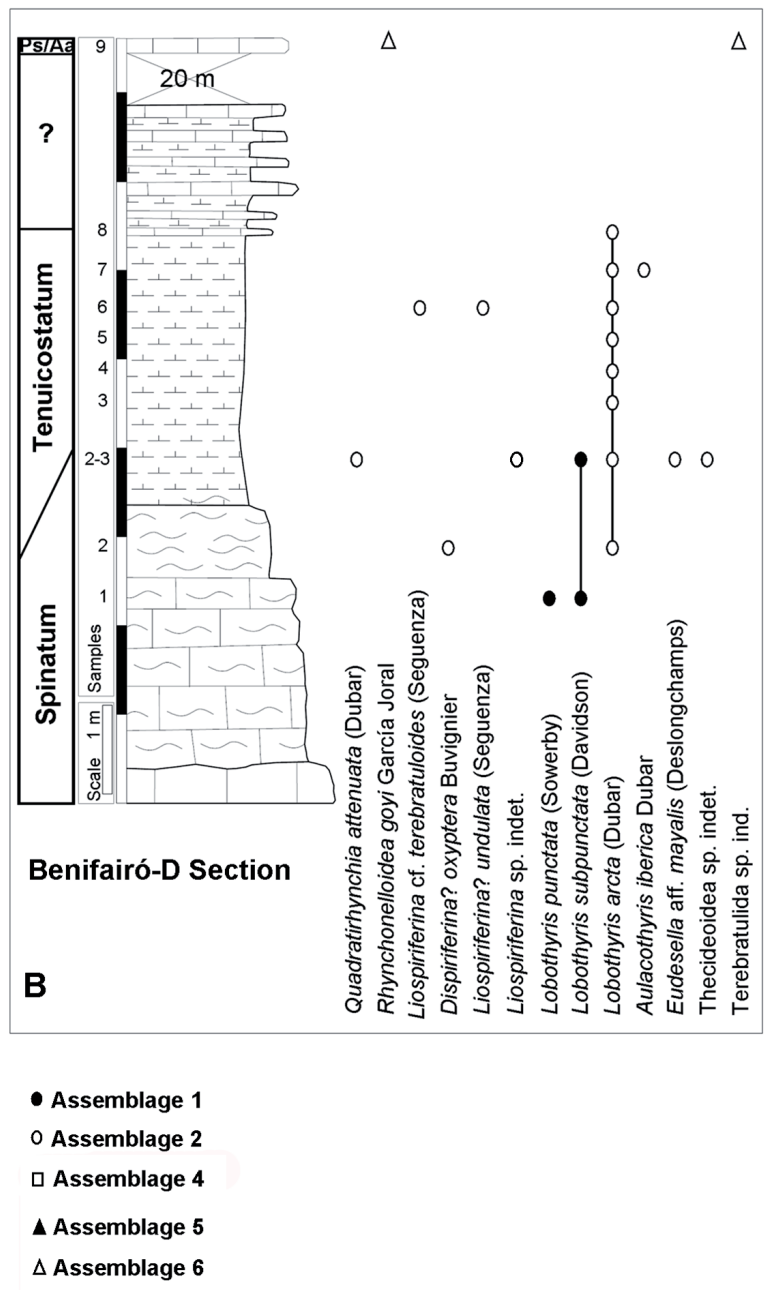

Fig. 5.- Distribution of the assemblages and brachiopod occurrences in (A) Racó de Joana and (B) Benifairó-D sections.

similarity with the type-species of Eudesella is evident but some features do not entirely fit into the diagnosis of the Deslongchamps' species, even taking into account the intraspecific variability accepted for this species (Pajaud, 1970).

The Ibero-Levantine representatives of Eudesella aff. mayalis (Fig. 8) show elongate concavo-convex to plano-convex shells, with a long hinge line and wide and low cardinal areas bearing a well-developed pseudodeltidium. Shells are smooth, with strong growth lines. Pedicle valve is highly convex and thickened, showing the attachment scar on its posterior third. Brachial valve internally shows from 9 to 12 long septa interdigitating with their successive deep lobes. The median septum is stronger and it has attached the closest lateral septum on each side, often developing a central protuberance. Cardinal process is well-developed and at times 
connected with two lateral ridges. Interior of pedicle valve shows a distinctive subperipheral rim.

This is an unusual fauna in the Western Tethys Ocean as a whole (Fig. 9). Thecideid fauna is only recorded in a comparable stratigraphic situation (though non-conspecific with the Iberian ones) in regions of somewhat higher palaeolatitudes (South England-Normand basins), forming part of the socalled Leptaena beds or Koninckella faunas (e.g. Davidson, 1851; Deslongchamps, 1853; Moore, 1855), or even in their German counterparts (Rau, 1905).

Referring to the peri-Iberian platforms, in those basins where koninckinid faunas have been reported, such as the Lusitanian basin (e.g. Alméras et al., 1988; Comas-Rengifo et al., 2013, 2015) or even in the Mediterranean Subbetic area (Baeza-Carratalá, 2013; Baeza-Carratalá et al., 2015), thecideids have not been documented as constituents of such assemblage.

\subsection{Predominance of the genus Lobothyris in the pre-ET- MEE assemblages}

Prior to the ETMEE, in the Early Jurassic peri-Iberian platforms system, the Last Occurrence Datum (LOD) of the genus Lobothyris, usually typified by $L$. gr. punctata-L. arcta never exceeds the LOD of the spiriferinids, which became extinct as effect of the ETMEE (Vörös, 2002; Comas-Rengifo et al., 2006). This distribution pattern is clearly evidenced in Asturias and Lusitanian basins (García Joral and Goy, 2009; García Joral et al., 2011; Comas-Rengifo et al., 2013, 2015) and such groups can be found at most coexisting together in the upper Semicelatum-lowermost Elegantulum subzones from the Aragonese branch of the Iberian Range (García Joral et al., 2011).

However, in the I-LS of the Iberian Range, the faunal succession Lobothyris punctata-L. subpunctata-L. arcta makes up the prevailing taxa in terms of abundance in the pre-ETMEE assemblages, accounting for nearly $80 \%$ specimens and showing an increasing trend representing a bloom in the last pre-ETMEE levels. This bioevent is even more patent in the southernmost outcrops of this region (Racó de Joana and Benifairó-D localities), where Lobothyris representatives can be recorded clearly exceeding the LOD of Liospiriferina? undulata (Fig. 5). After the ETMEE, the genus Lobothyris is doubtfully recorded in several localities of the I-LS and the innermost areas of the Iberian Range. It is represented by specimens attributed to L.? hispanica (Fig. 7), as constituent of the "Spanish Bioprovince" of brachiopods occurring in the Serpentinum-lower Bifrons zones.

On the contrary, the high diversification and radiation underwent by the Liospiriferina falloti group and very closely related taxa, which is conspicuous along the PliensbachianToarcian transition virtually throughout the Iberian Range, is not evident in the I-LS, where this group is represented only by very scarce specimens of Liospiriferina nicklesi and $L$. cf. terebratuloides.

\subsection{Soaresirhynchia bouchardi as pervasive post-ETMM opportunistic species}

The post-ETMEE pattern of repopulation led by $S$. bouchardi, mainly recorded in the Elegantulum Subzone from many Western Tethyan basins, is distinctive of an opportunistic strategy occupying vacant habitats in both epicontinental (e.g. García Joral and Goy, 2000; García Joral et al., 2011; Comas-Rengifo et al., 2013, 2015) and epioceanic areas (e.g. Baeza-Carratalá et al., 2011; Baeza-Carratalá, 2013) of the peri-Iberian platforms. In the I-LS this pattern is verified, as the onset of the repopulation phase is recorded as monospecific levels of this taxon, which shows abundant populations with high intraspecific variability, including several of the morphotypes classically recognized in this species (Figs. $4,6)$. The last horizons containing $S$. bouchardi in this region evidence a transitional record leading to the onset of the overlying Assemblage 4, since $S$. bouchardi temporarily cooccurs with several species of this assemblage (Fig. 4).

\subsection{Earlier onset of the Assemblage 5}

After the ETMEE, during the Middle-Upper Toarcian and even in the Aalenian, the distribution of the brachiopod faunal successions in the Iberian Range is markedly conditioned by the depositional sequences, particularly by the frequent variations on the bedding thickness and facies (García Joral et al., 1990). The transition from the predominantly marly Turmiel Fm. to the carbonate sediments (Casinos Fm.) in the Toarcian occurs earlier in the I-LS than in the remaining regions of the Iberian Range. Thus, the onset of the carbonate facies can be regarded as diachronic (Fig. 2), as it is dated in the Bifrons-Variabilis zones in this sector, while it is dated in the northernmost areas of the basin as Early Bajocian and, in

Fig. 6.- (next page) Some representative species of the Assemblages 1, 2 and 3 from the Ibero-Levantine sector of the Iberian Range. 1, 2: Assemblage 1 from the Spinatum-lowermost Tenuicostatum zones. 1: Aulacothyris resupinata (Sowerby), specimen SC1.A1 from Sot de Chera section. 2: Lobothyris subpunctata (Davidson), specimen SL7-Ls1 from Racó de Joana section. 3-11: Assemblage 2 from the Tenuicostatum Zone. 3: Aulacothyris iberica Dubar, specimen SLU.A1 from Racó de Joana section. 4, 5: Lobothyris arcta (Dubar): (4) specimen DB3.Ar1 and (5) DB4.Ar1 from Benifairó-D section. 6, 7: Liospiriferina? undulata (Seguenza): (6) specimen SL5.Un1 and (7) specimen SL5.Un2 from Racó de Joana section. 8: Eudesella aff. mayalis (Deslongchamps), specimen SC1a.Em5 from Sot de Chera section. 9: Liospiriferina cf. terebratuloides (Seguenza), specimen DB6.Te1 from Benifairó-D section. 10: Dispiriferina? oxyptera (Buvignier), specimen SL7.Ox1 from Racó de Joana section. 11: Quadratirhynchia attenuata (Dubar), specimen SLG.At.1 from Racó de Joana section. 12, 13: Assemblage 3. Soaresirhynchia bouchardi (Davidson), specimens SC2a.bo1 (12) and SC3t.bo1 (13) from the lowermost Serpentinum Zone of Sot de Chera section. a: dorsal, b: lateral, and c: anterior views, except for 8 (a: internal dorsal view). 


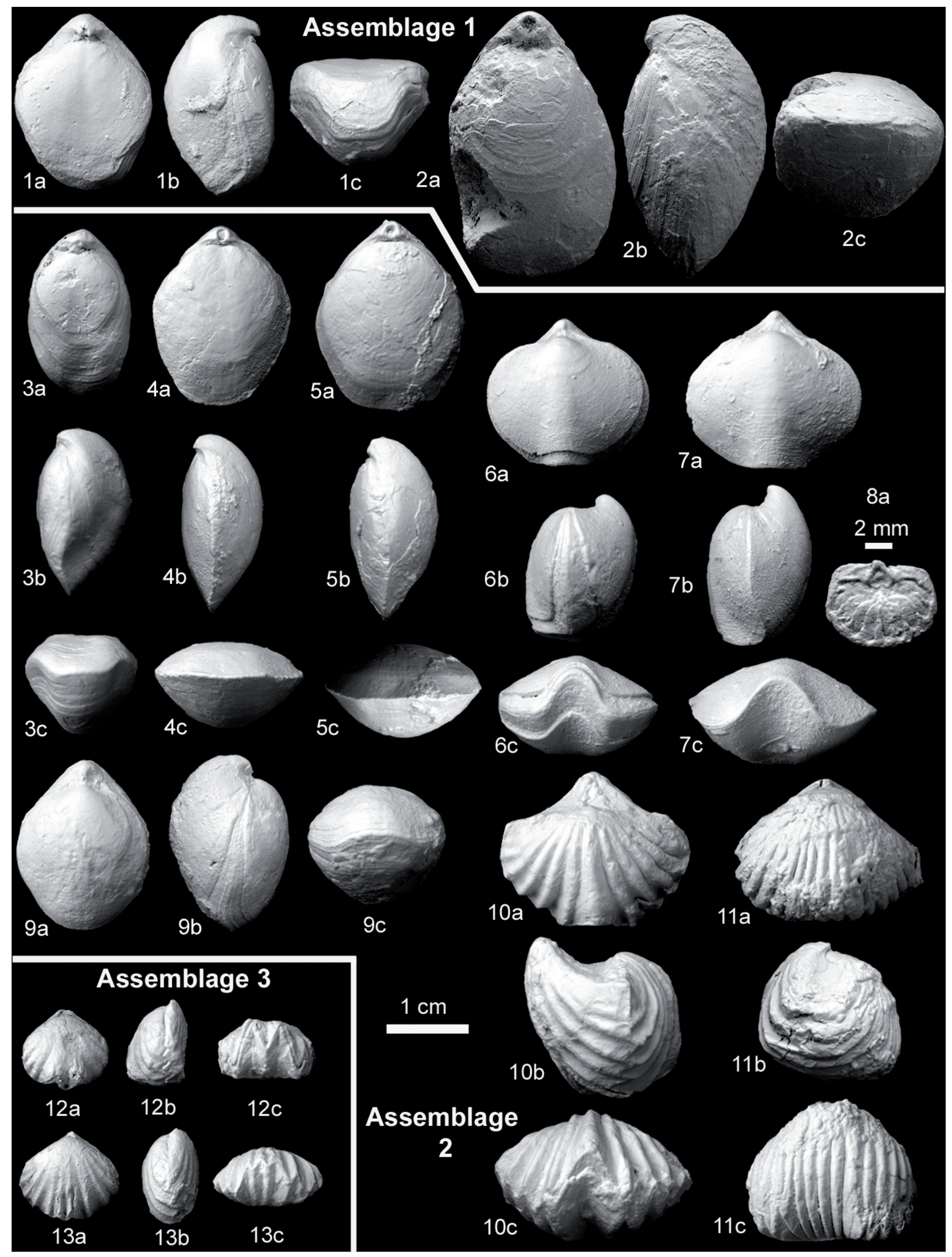


the north of the Castilian branch, it even corresponds to the Pseudoradiosa Zone (Gómez, 1979).

This premature change in the depositional environment predisposed the earlier record of some constituents making up the Assemblage 5, some of them even showing similar morphotypes to the components forming part of the Assemblage 6 recorded in the Pseudoradiosa-Aalensis zones (e.g. Rhynchonelloidea aff. goyi). In this sense, García Joral et al. (1990) ascertained that, in the Iberian Range, the FOD of $R$. goyi occurs in the upper Pseudoradiosa-lowermost Aalensis zones, but if a steady calcareous sedimentation persists, $R$. goyi can occur up to the uppermost Aalensis Zone.

To some extent, similar conditions could take place in the I-LS, as comparable morphotypes to $R$. goyi $(R$. aff. goyi) have been recorded in the first levels of the Casinos Fm. (Figs. 3, 4), with a prevailing calcareous component (Bifrons-Variabilis zones), preceding the "true R. goyi s.s.".

Otherwise, $R$. goyi s.s. is recorded in the I-LS in the predominantly grayish limestone upper levels of the BenifairóD section (Fig. 5), which typifies the Iberian-Mediterranean biogeographic district in the Pseudoradiosa-Aalensis zones (Andrade et al., 2016). R. aff. goyi is distinguished from $R$. goyi for its smaller size and less dense costation, otherwise they are very similar in morphology.

These sedimentological differences can also have influenced the appearance of Telothyris specimens with elevated sulciplication (Telothyris sp. 1) similar as observed in some species of the genus Stroudithyris such as S. stephanoides (Fig. 7). These forms are coeval with Stroudithyris aff. infraoolithica, but can be distinguished from this stock by the more acute sulciplication and by the decisive beak features. Stroudithyris representatives show large and oval foramina while they are smaller and rounded in Telothyris. We have considered these forms as Telothyris sp. 1 because they do not show enough diagnostic criteria to include them in any of the several varieties or species described for this genus.

This homeomorphism agrees with the aforementioned strong influence of the depositional sequences in the basin, as $S$. stephanoides prevails in the calcareous depositional environments from the Aalensis Zone onwards, being replaced by $S$. pisolithica as dominant taxon in more marly deposits (García Joral et al., 1990). Maybe, from an anagenetic perspective, this stock might represent a link between the last Telothyris species and the earliest records of Stroudithyris, but more accurate systematic analysis is required, including some comparable records from different areas and basins.

\subsection{Hiatus in the brachiopod record}

In the surveyed outcrops, brachiopods are not recorded in the Thouarsense-Dispansum chronozones either due to a stratigraphical gap in the sequences (e.g. Benifairó-D section, Fig. 5) or as results of a barren interval concerning the brachiopod fauna (e.g. Sot de Chera section, Fig. 4). The diversity of brachiopods is also minimal in this interval in other sectors of the Iberian Range, although some taxa have been recorded in localities with more marly sedimentation, such as Ariño or Rambla del Salto (García Joral and Goy, 2004). The next subsequent record in the I-LS corresponds to the Assemblage 6 (Fig. 5), showing lesser diversity in this region than in the northernmost localities from the Iberian Range.

\subsection{Under-representation of the Zeilleriidae}

In contrast to the remaining areas of the Iberian Range, zeillerids are scarcely recorded in the I-LS. They are restricted to the species of Aulacothyris in the PliensbachianToarcian transition and to the occasional occurrence of a few specimens of Neozeilleria cf. lycetti in the Assemblage 5. Zeilleriid taxa typify several intervals in diverse northerly localities of the Iberian Range (e.g. Zeilleria quadrifida, Z. sarthacensis, Z. culeiformis, Aulacothyris blakei), but they are not recorded in the analysed outcrops probably due to the aforementioned strong influence of the sedimentary conditions. Since, in spite of their virtually homogeneous distribution in the Iberian Range as a whole, they are more conspicuous in shallow marly environments or, at least, with more terrigenous input (cf. García Joral et al., 1990).

Southwards, in the neighboring Subbetic area, the pre-ETMEE zeilleriid record is mainly characterized by Bakonyithyris, Securina and several typical Mediterranean species of Zeilleria (Baeza-Carratalá, 2013; Baeza-Carratalá and García Joral, 2014), which are not recorded in the I-LS either.

\section{Conclusions}

Brachiopod fauna in the Late Pliensbachian-Late Toarcian from the Ibero-Levantine sector of the Iberian Range

Fig. 7.- (next page) Some representative species of the Assemblages 4 and 5 from the Ibero-Levantine sector of the Iberian Range. 1-6: Assemblage 4 from the the Serpentinum-lowermost Bifrons zones. 1, 2: Homoeorhynchia meridionalis (Deslongchamps): 1, specimen SC30.Hm1 and 2, specimen SC30a.Hm1 from Sot de Chera section. 3: Homoeorhynchia batalleri (Dubar), specimen SC3t.Ba1 from Sot de Chera section. 4: Pseudogibbirhynchia gr. jurensis (Quenstedt), specimen SL2b.Ju1 from Racó de Joana section. 5: Telothyris jauberti (Deslongchamps), specimen SC31.Tj1 from Sot de Chera section. 6: Lobothyris? hispanica (Dubar), specimen SC30a.Hi.1 from Sot de Chera section. 7-15: Assemblage 5 from the Bifrons-Variabilis zones. 7, 8: Rhynchonelloidea aff. goyi García Joral: 7, specimen SC4b.Afg1 and 8, specimen SCAs5. Afg1 from Sot de Chera section. 9: Choffatirhynchia aff. turolensis García Joral and Goy, specimen SC4B.Tu1 from Sot de Chera section. 10, 11: Homoeorhynchia? marini (Rousselle): 10, specimen SC4a.Hm1 from Sot de Chera section; 11, specimen SL1.Hm1 from Racó de Joana section. 12, 13: Homoeorhynchia pusilla García Joral and Goy: 12, specimen SC4a.Hp1 and 13, specimen SC4a.Hp2 from Sot de Chera section. 14. Telothyris sp. 1, specimen SC4b.Tel1 from Sot de Chera section. 15. Stroudithyris aff. infraoolithica (Deslongchamps), specimen SL1.Si1 from Racó de Joana section. a: dorsal, b: lateral, and c: anterior views. 


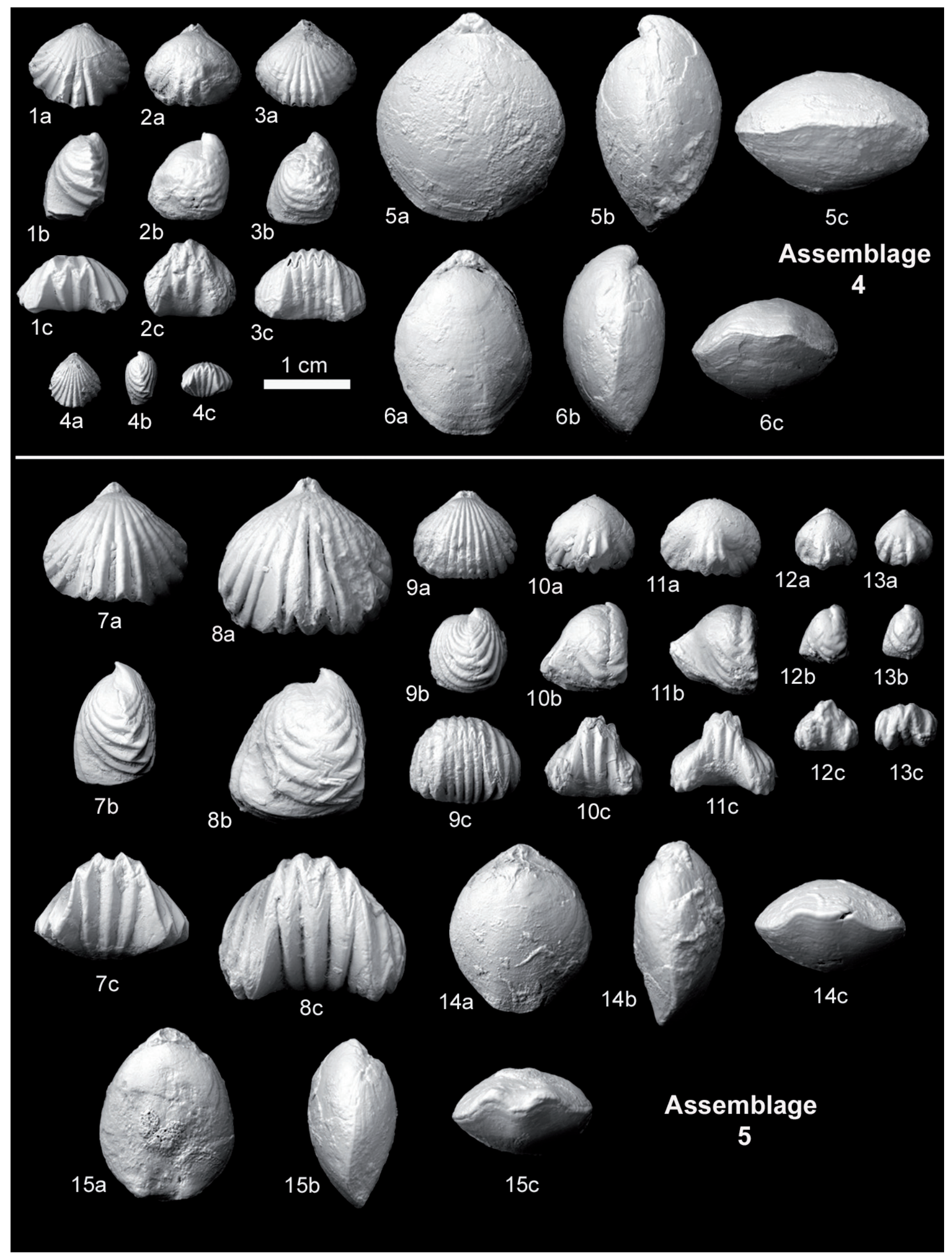




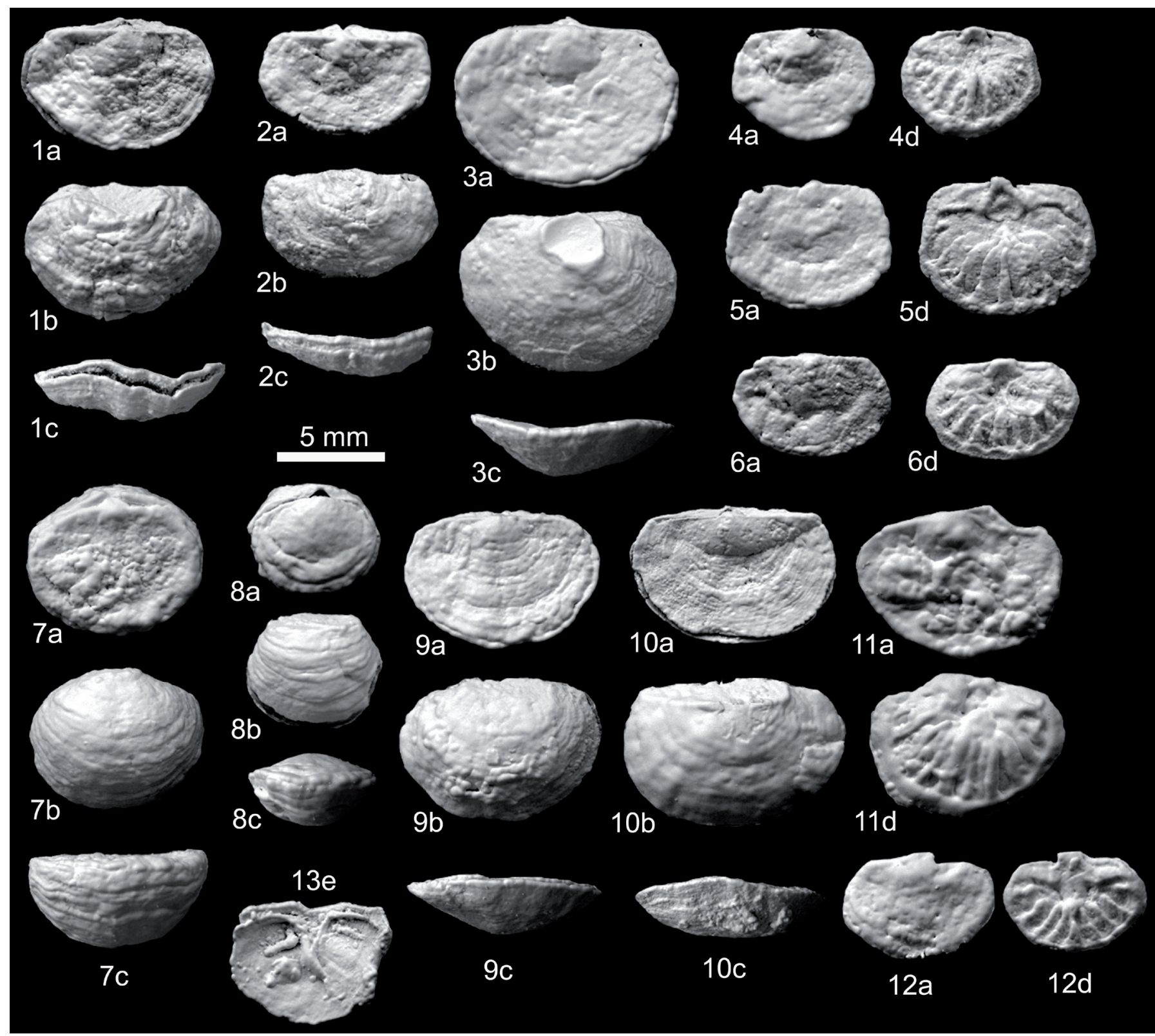

Fig. 8.- Some representative specimens of the "thecideid beds", typifying marker beds in the Assemblage 2 from the Tenuicostatum Zone of the Ibero-Levantine sector of the Iberian Range. 1-6: Eudesella aff. mayalis (Deslongchamps) from Sot de Chera section: 1. SC1a.Em1 specimen; 2. SC1a.Em2 specimen; 3. SC1a.Em3 specimen; 4. SC1a.Em4 specimen; 5. SC1a.Em5 specimen; 6. SC1a.Em6 specimen. 7, 9-13: Eudesella aff. mayalis (Deslongchamps), from Racó de Joana section: 7. SL4.Em1 specimen; 9. SL5.Em1 specimen; 10. SL5.Em2 specimen; 11. SL5. Em3 specimen; 12. SL5.Em4 specimen; 13. SL5.Em5 specimen. 8. Thecideida sp. ind. from Racó de Joana section: SL4.Em2 specimen. Images of each specimen are ordered consecutively in (a) external dorsal, (b) external ventral, (c) anterior, (d) internal dorsal, and (e) internal ventral views.

has been arranged for the first time into six assemblages and calibrated with the exhaustively controlled biochronological data available in the Iberian Range. The succession of the assemblages, consisting of 29 species, shows a discontinuous stratigraphic distribution since its diversity dynamics is markedly conditioned by the extinction phases linked to the ETMEE in the region.

The faunal succession shows strong affinities with that recorded in the remaining epicontinental platforms from the Iberian Range, because almost all the species are represented in the NW-European (Euro-Boreal) province, the transitional or even "Betic" (i.e. Mediterranean) palaeogeographical affinity previously attributed to the southernmost part of this region, can be confidently ruled out.

Amidst the main brachiopod-based bioevents must be considered the predominance of the genus Lobothyris in the pre-ETMEE assemblages, the conspicuous record of Liospiriferina? undulata and, especially, the first evidence in the Iberian Peninsula of Jurassic pre-ETMEE thecideid marker beds mostly made up by Eudesella aff. mayalis, allowing potential correlations with somewhat higher palaeolatitude regions. 


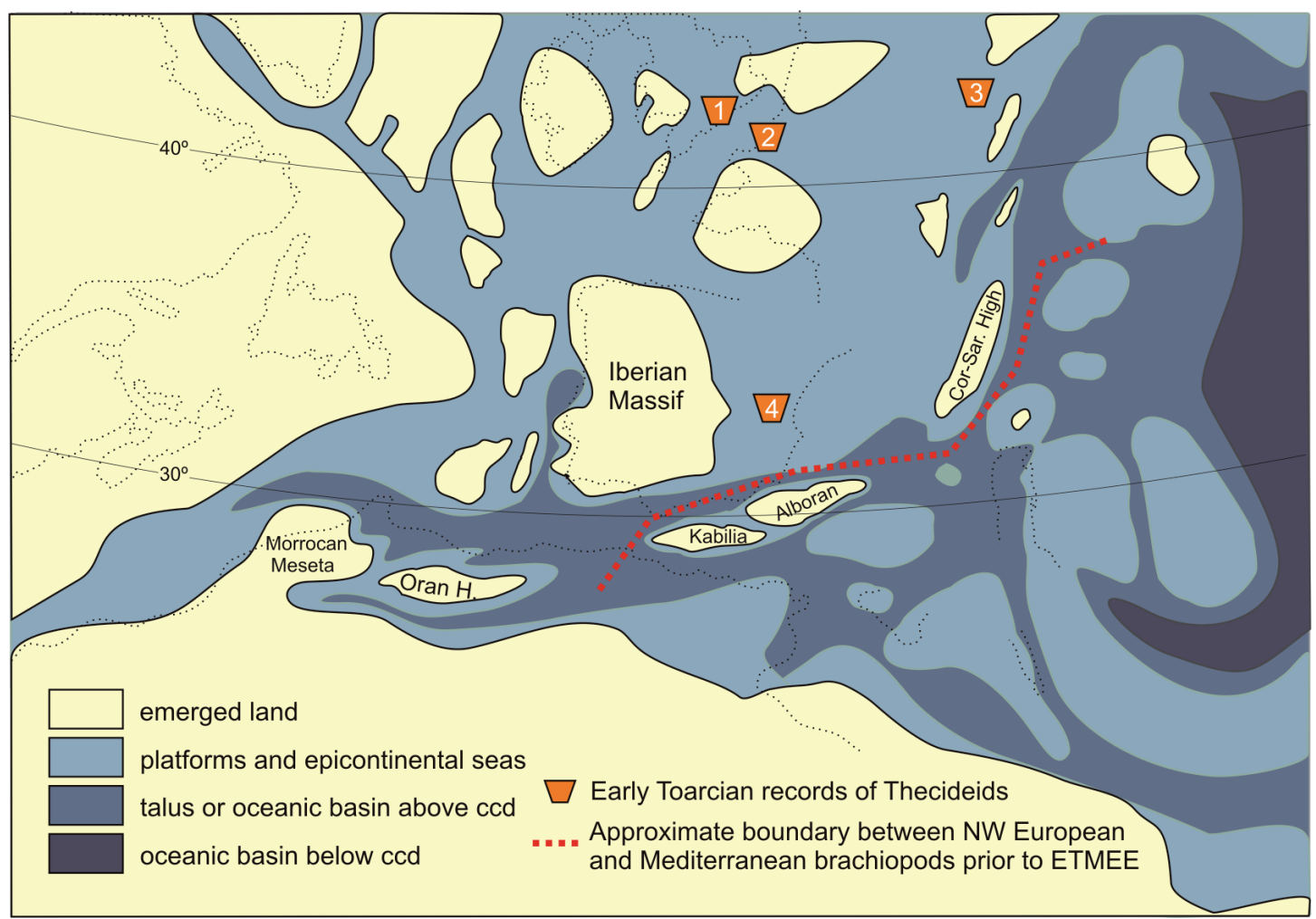

Fig. 9.- Paleogeographical map of the Western Tethys in the Early Toarcian (slightly modified after Bassoullet et al., 1993) showing the boundary between brachiopod provinces and the occurrence of Thecideids. 1: South England; 2: Normandy; 3: South Germany; 4: Ibero-Levantine Sector of the Iberian Range.

During the Middle-Upper Toarcian, the distribution of the brachiopod assemblages in the Ibero-Levantine sector is markedly influenced by the depositional sequences, entailing premature turnovers and involving the earlier record of homeomorphic morphotypes of younger terebratulides and rhynchonellides. Sedimentary conditions may have caused the under-representation of zeillerids as well.

\section{Acknowledgements}

This study is a contribution to the project CGL201566604-R (MINECO/FEDER) and is also partially supported by the Research Group VIGROB-167 (University of Alicante). The early draft of this work benefited greatly from the valuable comments by M.O. Manceñido. Useful comments from reviewers (M. Siblík, B. Radulović, and D.A. Ruban) and Journal Editors are also deservedly acknowledged.

\section{References}

Ager, D.V. (1967): Some Mesozoic Brachiopods in the Tethys region. In: C.G. Adams, D.V. Ager (eds.), Aspects of Tethyan Biogeography, Systematics Association Publication 7, 135-151.

Ager, D.V. (1971): Space and time in brachiopod history. In: F. Middlemiss, P. Rawson, G. Newall (eds.), Faunal Provinces in Space and Time. Geological Journal, Special Issue 4, 95-110.

Alméras, Y. (1987): Les brachiopodes du Lias-Dogger: Paléontologie et biostratigraphie. In R. Enay (coord.): Le Jurassique d'Arabie saoudite centrale. Geobios, M.S. 9, 161-219. doi:10.1016/S00166995(87)80073-6.
Alméras, Y., Mouty, N. (2001): Les Brachiopodes du Jurassique de Syrie. Revue de Paléobiologie 20, 9-17.

Alméras, Y., Cougnon, M., Enay, R., Mangold, C. (2010): Brachiopodes du Jurassique Inférieur et moyen d'Arabie Saoudite centrale. Documents des Laboratoires de Géologie de Lyon 168, 1-247.

Alméras, Y., Elmi, S., Mouterde, R., Ruget, C., Rocha, R. (1988): Evolution Paléogéographique du Toarcien et influence sur les peuplements, In: R.B. Rocha, A.F. Soares (eds.), International Symposium on Jurassic Stratigraphy, Lisboa, pp. 687-698.

Andrade, B. (2006): Los braquiópodos del tránsito Jurásico InferiorMedio de la Cuenca Lusitánica (Portugal). Coloquios de Paleontología 56, 5-194.

Andrade, B., Duarte, L.V., García Joral, F., Goy, A., Henriques, M.H. (2016): Palaeobiogeographic patterns of the brachiopod assemblages of the Iberian Subplate during the Late Toarcian-Early Aalenian (Jurassic). Palaeogeography, Palaeoclimatology, Palaeoecology 442, 12-22. doi:10.1016/j.palaeo.2015.10.053.

Baeza-Carratalá, J.F. (2013): Diversity patterns of Early Jurassic brachiopod assemblages from the westernmost Tethys (Eastern Subbetic). Palaeogeography, Palaeoclimatology, Palaeoecology 381-382, 76-91. doi: 10.1016/j.palaeo.2013.04.017.

Baeza-Carratalá, J.F., García Joral, F. (2012): Multicostate zeillerids (Brachiopoda, Terebratulida) from the Lower Jurassic of the Eastern Subbetic (SE Spain) and their use in correlation and paleobiogeography. Geologica Acta 10 (3), 1-12. doi: 10.1344/105.000001699.

Baeza-Carratalá, J.F., García Joral, F. (2014): Crural bases position as a structural criterion for supraspecific diagnosis of Early Jurassic zeilleriid brachiopods. Acta Palaeontologica Polonica 59 (3), 651-661. doi:10.4202/app.2012.0068.

Baeza-Carratalá, J.F., García Joral, F., Tent-Manclús, J.E. (2011): Biostratigraphy and palaeobiogeographic affinities of the Jurassic brachiopod assemblages from Sierra Espuña (Maláguide Complex, Internal Betic Zones, Spain). Journal of Iberian Geology 37 (2), 137-151. 
doi: 10.5209/rev JIGE.2011.v37.n2.3.

Baeza-Carratalá, J.F., Sepehriannasab, B. (2014): Early Jurassic (latest Toarcian) brachiopods from the northeastern margin of the Western Tethys (Central Iran) and their paleobiogeographical significance. Geobios 47, 3-17. doi: 10.1016/j.geobios.2013.12.002.

Baeza-Carratalá, J.F., García Joral, F., Giannetti, A., Tent-Manclus, J.E. (2015): Evolution of the last koninckinids (Athyridida, Koninckinidae), a precursor signal of the Early Toarcian mass extinction event in the Western Tethys. Palaeogeography, Palaeoclimatology, Palaeoecology 429, 41-56. doi: 10.1016/j.palaeo.2015.04.004.

Baeza-Carratalá, J.F., García Joral, F., Tent-Manclús, J.E. (2016): Brachiopod faunal exchange through an epioceanic-epicontinental transitional area from the Early Jurassic South-Iberian platform system. Geobios, 49, 243-255. doi: 10.1016/j.geobios.2016.05.005.

Bizon, G., Champetier, Y., Guérin-Franiatte, S., Rollet, A. (1966): Présence de Bouleiceras nitescens dans l'est des Cordillères bétiques. Bulletin de la Société Géologique de France 8, 901-904.

Calzada, S. (1979): Niveles de braquiópodos del Lías de Camarasa (Lérida). Cuadernos de Geología Universidad de Granada 10, 197-211.

Caswell, B.A., Coe, A.L., Cohen, A.S. (2009): New range data for marine invertebrate species across the Early Toarcian (Early Jurassic) mass extinction. Journal of the Geological Society of London 166, 859-872. doi: 10.1144/0016-76492008-0831

Champetier, Y. (1971): Le Jurassique dans la partie Orientale des Zones Externes des Cordillères Bétiques. Description et Corrélation des facies du Jurassique à l'Est du Rio Albaida. Cuadernos de Geología Ibérica 2, 125-136.

Champetier, Y. (1972): Le Prébétique et Ibérique côtiers dans le Sud de la Province de Valence et le Nord de la Province d'Alicante (Espagne). Nancy (Thèse Doctoral) Sciences de la Terre. Mémoire 24, $170 \mathrm{pp}$.

Chiocchini, M., Fazzuoli, M., Pavia, G. (2002): The Uanei Formation (Toarcian) in the Iscia Baidoa Area, South Western Somalia. In: L. Martire (ed.), 6th International Symposium on the Jurassic System. Abstracts and Program, Mondello, pp. 33-34.

Colás Gracia, J. (2015): Los Rinconélidos (Brachiopoda, Rhynchonellida) del intervalo Calloviense-Oxfordiense en el Sector Central de la Cordillera Ibérica. Unpublished Doctoral Thesis. Universidad de Zaragoza, $265 \mathrm{pp}$.

Comas-Rengifo, M.J., Goy, A. (1975): Estratigrafía y paleontología del Jurásico de Ribarredonda (Guadalajara). Estudios Geológicos 31, 297-339.

Comas-Rengifo, M.J., Gómez, J.J., Goy, A., Herrero, C., Perilli, N., Rodrigo, A. (1998): El Sinemuriense y el Pliensbachiense de Alfara, Cordillera Costero-Catalana (Tarragona). Cuadernos de Geología Ibérica 24, 161-173.

Comas-Rengifo, M.J., García-Joral, F., Goy, A. (2006): Spiriferinida (Brachiopoda) del Jurásico Inferior del NE y N de España: distribución y extinción durante el evento anóxico oceánico del Toarciense inferior. Boletín de la Real Sociedad Española de Historia Natural, Sección Geológica 101, 147-157.

Comas-Rengifo, M.J., Duarte, L.V., García Joral, F., Goy, A. (2013): Los braquiópodos del Toarciense Inferior (Jurásico) en el área de RabaçalCondeixa (Portugal): distribución estratigráfica y paleobiogeografía. Comunicações Geológicas 100 (1), 37-42.

Comas-Rengifo, M.J., Duarte, L.V., Félix, F.F., García Joral, F., Goy, A., Rocha, R.B. (2015): Latest Pliensbachian-Early Toarcian brachiopod assemblages from the Peniche section (Portugal) and their correlation. Episodes 38 (1), 2-8.

Cooper, G. A. (1989): Jurassic brachiopods of Saudi Arabia. Smithsonian Contributions to Paleobiology 65, 1-139. doi: 10.5479/ si.00810266.65.1

Davidson, T. (1851): A Monograph of the British Fossil Brachiopoda (Vol. 1, Part 3: The Oolitic and Liasic Brachiopoda). Palaeontogra- phical Society (London) Monograph 4, 1-64.

Delance, J.H. (1969): Etude de quelques Brachiopodes liassiques du Nord-Est de l'Espagne. Annales de Paléontologie, (Invertébrés) 55 (1), 1-44.

Delance, J.H. (1972): Problèmes posés par la variation géographique des espèces, leurs implications stratigraphiques. Exemples pris chez les Brachiopodes jurassiques. Mémoire du Bureau des Recherches Géologiques et Minières 77, 69-75.

Deslongchamps, E.E. (1853): Mémoire sur les genres Lœptaena et Thecidea des terrains Jurassiques du Calvados. Mémoires de la Société Linnéenne de Normandie 9, 213-250.

Dommergues, J.L., Meister, C., Mouterde, R. (1997): Pliensbachien. In: P. Hantzpergue, E. Cariou (eds.), Biostratigraphie du Jurasique ouest européen et méditerranéen. Bulletin du Centre Recherche Elf, Exploration et Production 17, 15-23.

Dubar, G. (1931): Brachiopodes liassiques de Catalogne et des régions voisines. Butlletí Institució Catalana Historia Natural 31, 103-180.

Elmi, S., Gabilly, J., Mouterde, R. (1997): Toarcién. In: P. Hantzpergue, E. Cariou (eds.), Biostratigraphie du Jurasique ouest européen et méditerranéen. Bulletin du Centre Recherche Elf, Exploration et Production 17, 25-36.

Fernández-López, S., García Joral, F., Gómez, J.J, Henriques, M.H.P., Martínez, G. (1998): La diferenciación paleogeográfica de la Cuenca Catalana al principio del Jurásico Medio. Revista de la Sociedad Geológica de España 11 (1-2), 3-22.

Gahr, M.E. (2002): Palökologie des Makrobenthos aus dem Unter-Toarc SW-Europas. Beringeria 31, 3-204.

García Joral, F., Goy, A. (1984): Características de la fauna de braquiópodos del Toarciense Superior en el Sector Central de la Cordillera Ibérica (Noreste de España). Estudios Geológicos 40, 55-60.

García Joral, F., Goy, A. (1994): The associations of brachiopods from the Toarcian-Aalenian transition in the Fuentelsaz section (Iberian Range, Spain). Geobios (mém. sp.) 17, 223-228. doi:10.1016/S00166995(94)80141-X.

García Joral, F., Goy, A. (2000): Stratigraphic distribution of Toarcian brachiopods from the Iberian Range (Spain) and its relation to depositional sequences. Georesearch Forum 6, 381-386.

García Joral, F., Goy, A. (2004): Caracterización de Choffatirhynchia nov. gen. (Brachiopoda, Rhynchonellida) en el Toarciense (Jurásico) de la Cordillera Ibérica (España). Boletín de la Real Sociedad Española de Historia Natural 99, 237-250.

García Joral, F., Goy, A. (2009): Toarcian (Lower Jurassic) brachiopods in Asturias (Northern Spain): stratigraphic distribution, critical events and palaeobiogeography. Geobios 42, 255-264. doi:10.1016/j.geobios.2008.10.007.

García Joral, F., Goy, A. (2010): Biozonas de Rhynchonellida (Brachiopoda) del Toarciense de las Cordilleras Ibérica y Cantábrica (España). V Congreso del Jurásico de España. Museo del Jurásico de Asturias, Colunga, pp. 65-72.

García Joral, F., Goy, A., Ureta, S. (1990): Las sucesiones de braquiópodos en el tránsito Lías-Dogger en la Cordillera Ibérica. Cuadernos de Geología Ibérica 14, 55-65.

García Joral, F., Gomez, J.J., Goy, A. (2011): Mass extinction and recovery of the Early Toarcian (Early Jurassic) brachiopods linked to climate change in northern and central Spain. Palaeogeography, Palaeoclimatology, Palaeoecology 302, 367-380. doi: 10.1016/j.palaeo.2011.01.023.

Gómez, J.J. (1979): El Jurásico en facies carbonatada del sector Levantino de la Cordillera Ibérica. Tesis Doctoral. Seminarios de Estratigrafía (monog.) 4, 683 pp.

Gómez, J.J., Goy, A. (1979): Las unidades litoestratigráficas del Jurásico medio y superior en facies carbonatadas del Sector Levantino de la Cordillera Ibérica. Estudios Geológicos 35, 17-57.

Gómez, J.J., Goy, A. (1981): Evolución lateral de las unidades litoes- 
tratigráficas en facies carbonatadas de la Cordillera Ibérica. Cuadernos de Geología Universidad de Granada 10, 83-93.

Gómez, J.J., Goy, A. (2000): Definition and organization of limestonemarl cycles in the Toarcian of the Northern and East-Central part of the Iberian Subplate (Spain). GeoResearch Forum 6, 301-310.

Gómez, J.J., Goy, A., (2005): Late Triassic and Early Jurassic palaeogeographic evolution and depositional cycles of the Western Tethys Iberian platform system (Eastern Spain). Palaeogeography, Palaeoclimatology, Palaeoecology 222, 77-94. doi:10.1016/j.palaeo.2005.03.010.

Gómez, J.J., Goy, A. (2011): Warming-driven mass extinction in the Early Toarcian (Early Jurassic) of northern and central Spain. Correlation with other time-equivalent European sections. Palaeogeography, Palaeoclimatology, Palaeoecology 306, 176-195. doi: 10.1016/j. palaeo.2011.04.018.

Gómez, J.J., Comas-Rengifo, M.J., Goy, A. (2003). Las unidades litoestratigráficas del Jurásico Inferior de las cordilleras Ibérica y Costeras Catalanas. Revista de la Sociedad Geológica de España 16 (3-4), 227-238.

Goy, A. (1974): El Lías de la mitad norte de la Rama Castellana de la Cordillera Ibérica. Tesis Doctoral Universidad Complutense de Madrid (inédita), $940 \mathrm{pp}$.

Goy, A., Martínez, G. (1990): Biozonación del Toarciense en el área de La Almunia de Doña Godina - Ricla (Sector Central de la Cordillera Ibérica). Cuadernos de Geología Ibérica 14, 11-53.

Goy, A., Robles, F. (1975): Resultado de un estudio sobre braquiópodos liásicos del NE de Guadalajara. Boletín de la Real Sociedad Española de Historia Natural (ext.) 1, 243-255.

Goy, A., Comas-Rengifo, M. J., García Joral, F. (1984): The Liassic brachiopods of the Iberian Range (Spain): Stratigraphic distribution and biozonation. International Symposium on Jurassic Stratigraphy, Erlangen 1, pp. 227-250.

Goy, A., García Joral, F., Gómez, J.J., Martínez, G., Ureta, S. (1997): El Toarciense en la región de Ariño. Rama Aragonesa de la Cordillera Ibérica, España. In: G. Meléndez, I. Pérez-Urresti (eds.). Comunicaciones IV Congreso del Jurásico de España, Alcalá de Henares, pp. 79-80.

Goy, A., Gómez, J.J., Yébenes, A. (1976). El Jurásico de la Rama Castellana de la Cordillera Ibérica (Mitad Norte). I. Unidades Litoestratigráficas. Estudios Geológicos 32, 391-423.

Goy, A., Jimenez, A., Martínez, G., Rivas, P. (1988): Difficulties in correlating the Toarcian ammonite succession of the Iberian and Betic Cordilleras. In: R.B. Rocha, A.F. Soares (eds.). 2nd. International Symposium on Jurassic Stratigraphy Centro de Estratigrafia e Paleobiologia, Universidade Nova de Lisboa, Lisboa, pp. 155-178.

Kaesler, R.L., Selden, P.A. (Eds.), (1997-2007): Treatise on Invertebrate Paleontology. Part H, Brachiopoda, Revised, Vols. 1-6. Geological Society of America and Paleontological Institute, Boulder, Colorado and Lawrence, Kansas.

Little, C.T.S., Benton, M.J. (1995): Early Jurassic mass extinction: A global long-term event. Geology 23, 495-498. doi: 10.1130/0091-7613(1995)023<0495:EJMEAG>2.3.CO.

Manceñido, M.O. (2002): Paleobiogeography of Mesozoic brachiopod faunas from Andean-Patagonian areas in a global context. Geobios 35 (M.S. 24), 176-192. doi: 10.1016/S0016-6995(02)00058-X.

Manceñido, M.O., Damborenea, S.E. (1990): Corallophilous micromorphic brachiopods from the Lower Jurassic of west central Argen- tina. In: D. MacKinnon, D. Lee, J.D. Campbell (eds.), Brachiopods Through Time. A.A. Belkema, Rotterdam, pp. 89-96.

Mayoral, E., Sequeiros, L. (1981): Significado paleoecológico de algunos epizoos y "borers" del Jurásico Inferior y Medio de Belchite (Zaragoza, Cordillera Ibérica). Cuadernos de Geología 10, 121-135.

Moore, C. (1855): On new Brachiopoda from the Inferior Oolite of Dundry. Proceedings Somersetshire Archaeological and Natural Society 5 [for 1854], 107-124.

Page, K.N. (2003): The Lower Jurassic of Europe: its subdivision and correlation. Geological Survey of Denmark and Greenland Buletin 1, 23-59.

Pajaud, D. (1970): Monographie des Thécidées (Brachiopodes). Mémoires de la Société Géologique de France (Nouvelle Série) 112, 349 pp.

Rau, K. (1905): Die Brachiopoden des mittleren Lias Schwabens mit Ausschluss der Spiriferinen. Geologische und Paläontologische Abhandlungen 10, 263-355.

Rousselle, L. (1977): Spiriférines du Lias moyen et supérieur au Maroc (Rides prérifaines, Moyen Atlas) et en Espagne. Notes et Mémoires du Service Géologique du Maroc 38, 153-175.

Seguenza, G. (1885): Le Spiriferina dei vari Piani del Lias messinese. Boletino della Società Geologica Italiana 4, 377-497.

Ruban, D.A., Vörös, A. (2015): Palaeobiogeographical affinity of the early Pliensbachian (Early Jurassic) brachiopod assemblage of the Northern Caucasus (Russia): A new evidence. Palaeogeography, Palaeoclimatology, Palaeoecology 430, 11-20. doi: 10.1016/j.palaeo.2015.04.006.

Thévenin, A. (1908). Paléontologie de Madagascar. Pt. V: Fossiles liasiques. Annales de Paléontologie 3, 105-143.

Vörös, A. (1977): Provinciality of the Mediterranean Lower Jurassic brachiopod fauna: causes and plate-tectonic implications. $\mathrm{Pa}$ laeogeography, Palaeoclimatology, Palaeoecology 21, 1-16. doi: 10.1016/0031-0182(77)90002-5

Vörös, A. (1984): Lower and Middle Jurassic brachiopod provinces in the western Tethys. Annales Universitatis Scientiarum Budapestinensis de Rolando Eötvös nominatae, Sectio Geologica 24, 207-233.

Vörös, A. (2002): Victims of the Early Toarcian anoxic event: the radiation and extinction of Jurassic Koninckinidae (Brachiopoda). Lethaia 35, 345-357. doi: 10.1111/j.1502-3931.2002.tb00093.x.

Vörös, A. (2016): Early Jurassic (Pliensbachian) brachiopod biogeography in the western Tethys: The Euro-Boreal and Mediterranean faunal provinces revised. Palaeogeography, Palaeoclimatology, Palaeoecology 457, 170-185. doi: 10.1016/j.palaeo.2016.06.016.

Vörös, A., Kocsis, Á.T., Pálfy, J. (2016): Demise of the last two spirebearing brachiopod orders (Spiriferinida and Athyridida) at the Toarcian (Early Jurassic) extinction event. Palaeogeography, Palaeoclimatology, Palaeoecology 457, 233-241. doi: 10.1016/j.palaeo.2016.06.022.

Wignall, P.B., Bond, D.P.G. (2008): The end-Triassic and Early Jurassic mass extinction records in the British Isles. Proceedings of the Geologists'Association 119, 73-84. doi: 10.1016/S0016-7878(08)80259-3

Wignall, P.B., Newton, R.J., Little, C.T.S. (2005): The timing of paleoenvironmental change and cause-and-effect relationships during the Early Jurassic mass extinction in Europe. American Journal of Science 305, 1014-1032.doi: 10.2475/ajs.305.10.1014. 